\title{
JENIS, FUNGSI, DAN MAKNA PADA FRASA DAN KATA MAJEMUK DALAM PUISI DON QUIXOTE KARYA GOENAWAN MOHAMAD
}

\author{
Ilfan Askul Pehala \\ Universitas Sebelas Maret, Surakarta \\ faizsaniyasnaini@gmail.com \\ Kun Andyan Anindita \\ Universitas Sebelas Maret, Surakarta \\ andyan_anindito@yahoo.co.id \\ M. Rosyidi \\ Universitas Sebelas Maret, Surakarta \\ mrosyidi65@gmail.com
}

\begin{abstract}
This study aims to describe phrases and compound words that have function and meaning in poetry. It used syntactic and semantic approach. The data sources of this study were two poems of Don Quixote. The data were collected by using reading and note-taking techniquesand analyzed by qualitative descriptive method, and then were explained formally and informally. The findings of this study indicate: (1) there are five phrases in the poetries that consist of determiner phrases (DP), noun phrase (NP), verb phrase (VP), adjective phrase (Adj. P) and prepositional phrase (Prep. P); (2) functions consisting of referential function, aesthetic function and communicative function; (3) meanings in the poetriescomprising denotative meaning, grammatical meaning, figurative meaning, idiomaticmeaning and connotative meaning; and (4) functiosn of the phrases and compound word in the poetries.
\end{abstract}

Key word: types, function, meaning, phrases, compound word

\begin{abstract}
ABSTRAK
Penelitian ini bertujuan untuk mengetahui, menganalisis dan mendeskripsikan frasa dan kata majemuk yang memiliki fungsi dan makna dalam puisi. Sumber data penelitian adalah dua puisi dari Don Quixote. Teknik pengumpulan data dilakukan teknik pembacaan dan teknik pencatatan atau simak catat dan dianalisis dengan teknik analisis deksriptif kualitatif secara formal dan informal.Hasil penelitian menunjukkan bahwa (1) jenis frasa yang ditemukan dalam kumpulan puisi ini ada lima, yaitu: frasa determiner/FD, frasa nominal (FN), frasa verba (FV), frasa ajektiva (F Adj.) dan frasa preposisional (F Prep.). (2) Fungsi yang dibedakan menjadi 3, yaitu referensial, puitis/estetis dan komunikatif. (3) Makna yang ada dalam sajak terdiri dari 5 yaitu denotatif, gramatikal, kiasan, idiom dan konotatif. (4) Fungsi frasa dan kata majemuk dalam sajak.
\end{abstract}

Kata Kunci: jenis, fungsi, makna, frasa, kata majemuk 


\section{PENGANTAR}

Masyarakat Indonesia pertama kali dikenalkan kepada cerita karangan Miguel de Cervantes ini oleh Abdul Moeis, seorang sastrawan angkatan Balai Pustaka. Abdul Moeis menerjemahkan cerita Don Quixote pada tahun 1933. Pada tahun 2011, Goenawan Mohamad menerjemahkan novel tersebut ke dalam jenis karya sastra yang lain yaitu puisi. Menurut Goenawan Mohamad, Carvantes sebenarnya hanya pencerita kedua, Carvantes mendengar kisah Don Quixote pertama kali dari Sayid Hamid Benengeli. Cerita Don Quixote berkisah tentang seorang lelaki yang terganggu kewarasannya karena terlalu banyak membaca kisah-kisah kepahlawanan. Dia percaya bahwa dia pun seorang ksatria. Bersama seorang petani buta huruf, Sancho Panza, Don Quixote kemudian bertualang. Dia melawan kincir angin yang dia sangka sebagai raksasa. Lukisan pasir kincir angin di sebuah tanah lapang pada layar perlahan-lahan berubah. Kincir tersebut kemudian dilengkapi dengan mata besar yang melotot dan kumis panjang lebat yang mengancam.

Sebuah karya sastra menjadi bernilai seni, indah, dan menghibur dalam banyak hal disebabkan oleh perpaduan yang harmonis antara unsur bentuk dan isi, cara mengungkapkan dan apa yang diungkapkan. Bentuk yang indah dengan muatan makna yang berbobot akan menjamin nilai literer karya yang bersangkutan. Unsur bentuk adalah yang pertama dijumpai pembaca ketika berhadapan dengan karya sastra. Dengan sedikit menyederhanakan masalah dapat dikatakan bahwa unsur bentuk itu yang paling utama adalah bahasa. Unsur bentuk lain seperti penggunanaan simbolisme atau permainan makna yang lain juga hanya dapat dikenali lewat bahasa.

Unsur bahasa dalam puisi bisa dikatakan lebih penting, lebih menentukan nilai keindahannya daripada unsur muatan makna. Nurgiyantoro (2014:70) menyatakan bahwa sebuah puisi yang gagal menangkap momen-momen puitis, gagal mendayakan berbagai aspek bahasa, boleh dikatakan gagal sebagai puisi yang memenuhi tuntutan keindahan apa pun muatan makna yang dikandungnya. Muatan makna dalam puisi tersebut bisa dikatakan mirip, tetapi kedua puisi itu bisa berbeda nilai keindahan, nilai literernya. Jika kreativitas dan pendayaan bahasa berbeda.

Suminto A. Sayuti (2008:3) secara sederhana merumuskan tentang puisi yang merupakan sebentuk pengucapan bahasa yang memperhitungkan adanya aspek bunyi-bunyi di dalamnya, yang mengungkapkan pengalaman imajinatif, emosional, dan inteletual penyair yang ditimba dari kehidupan individual dan sosialnya. Hal ini diungkapkan dengan teknik pilihan tertentu sehingga puisi itu mampu membangkitkan pengalaman tertentu pula dalam diri pembaca atau pendengarnya. Tentu saja, batasan ini merupakan batasan tentatif yang bertolak belakang pada puisi-puisi konvensional. Sebab, batasan itu pun belum mampu mencakupi semua jenis puisi yang ada.

Buku kumpulan puisi Don Quixote menarik untuk diteliti karena buku 
asli Don Quixote berbentuk novel dan diterjemahkan ke dalam puisi. Hal ini tentu saja membuat penyair tidak hanya mengubah narasi dari novel ke puisi tetapi juga bagaimana kumpulan puisi ini agar tetap utuh sebagai cerita yang bersumber dari novel. Buku kumpulan ini banyak ditemukan beberapa jenis frasa dan kata majemuk yang menarik itu diteliti seperti jenis, fungsi, dan makna yang terkandung dalam frasa dan kata majemuk yang terdapat dalam buku kumpulan puisi Don Quixote karya Goenawan Mohamad. Dalam buku ini, frasa dan kata majemuk bukan hanya membentuk rangkaian cerita yang ditulis dalam untaian puisi. Akan tetapi, semua itu membentuk alur makna yang jelas ataupun harus mendalami makna yang ada di balik itu semua. Makna frasa adalah makna gramatikal yang bisa dipahami secara jelas dan kata majemuk memiliki makna yang berbeda dari kata-kata penyusunnya yang lebih banyak mengarah ke makna idiomatis. Akan tetapi dalam buku ini, makna yang terkandung dalam frasa bisa menjadi begitu berbeda meskipun mereka bukan kata majemuk.

\section{TEORI DAN METODE PENELITIAN}

Mengenai frasa, Kridalaksana (1982:46) mendefinisikan frasa sebagai gabungan dua kata atau lebih yang sifatnya tidak predikatif. Beberapa sumber lainnya memiliki pandangan yang sama dalam mana frasa adalah satuan lingual yang memiliki inti (head) dan modifier ataupun complements (lihat Sportiche, Koopman, dan Stabler 2014, Carnie, 2002, dan Matthews, 1981). Mathews (1981:161-162) menjelaskan bahwa konstruksi sebuah frasa dapat ditetapkan seperti satu konstruksi yang memiliki inti dan sebuah frasa sebagai satu unit yang berperan seperti sebuah konstruksi. Sebuah frasa "A" (atau 'A-(i) al') secara rinci merupakan sebuah frasa yang inti dari konstruksinya adalah 'A'.

Namun, beberapa frasa terkadang sesuatu yang diasumsikan menjadi head bukanlah head di dalam frasa itu sendiri. Hal ini bisa dilihat pada frasa determiner dan frasa preposisional dalam mana head pada frasa ini bukanlah determiner ataupun preposisi. Akan tetapi, hal yang menjadi head adalah frasa nominal. Hal ini disebabkan determiner ataupun preposisi berperan sebagai complement dan modifier saja. Selain itu, kelas kata yang menjadi "ciri" dari frasa itu sendiri bukanlah dari open class categories seperti nomina, verba, ajektiva dan adverbia. Namun, ciri dari frasa ini dari close class categoriesdapat berupa preposisi, determiner, numeral, complementizers, kata kerja bantu, modals, coordinator dan negasi/ afirmasi (Sportiche, Koopman, dan Stabler, (2014:10).

Hal ini berbeda dengan frasa yangcirinya dari open class categories. Wujud dari hal itu adalah nomina, verba, ajektiva dan adverbia. Sesuatu yang terdapat pada frasa verba, frasa nomina, frasa ajektiva dan frasa adverbia dalam mana inti/head-nya adalah nomina, verba, ajektiva dan adverbia dan close class categories. Preposisi, determiner (berupa articles, demonstratives dan quantifiers), numeral, complementizers, kata kerja bantu, modals, coordinator dan negasi/afirmasi adalah modifier ataupun complemets. 
Sportiche, Koopman, dan Stabler (2014:105-119) membagi frasa menjadi lima jenis frasa tanpa frasa adverbial yaitu verb phrases (VP), determiner phrases (DP), noun phrases (NP), adjective phrases (Adj. P), dan prepositional phrases (Prep. P). Carnie (2002:144) juga menjelaskan mengenai determiner frase. Beberapa sumber lainnya seperti Matthews (1981) dan Kridalaksana (1982) menyebutkan bahwa frasa adverbial disebutkan, tetapi tidak menyebutkan adanya frasa determiner. Hal ini, misalnya, disampaikan oleh Kridalaksana (1982:46) yang mendefinisikan frasa adverbial sebagai adverbia induk dan adverbia lain sebagai modifikator atau partikel.

Kata majemuk dapat juga dijumpai dalam kumpulan puisi ini. Kata majemuk menurut Kridalaksana (1982:77) adalah gabungan morfem dasar yang seluruhnya berstatus sebagai kata yang mempunyai pola fonologis, gramatikal, dan semantis yang khusus menurut kaidah bahasa yang bersangkutan. Pola khusus tersebut membedakannya dari gabungan morfem dasar yang bukan kata majemuk. Sportiche, Koopman, dan Stabler (2014:28-29) juga menyebutkan kata majemuk merupakan kata yang diperoleh dengan menggabungkan kata-kata bukan morfem, yang disebut dengan compounds. Dalam bahasa Inggris, kata majemuk terkadang ditulis dengan spasi atau tanda penghubung di antara kata-kata itu dan terkadang spasi dan tanda penghubung juga tidak ada. Kadang kala, makna dari kata majemuk ini adalah idiomatis (maknanya tidaknya bisa diduga bila diartikan bagian- bagiannya) dan terkadang pula makna komposisi (maknanya ditentukan dalam cara lazim dengan bagian-bagiannya)

Berbicara frasa dan kata majemuk dalam puisi-puisi ini, hal ini juga harus dilihat tentang fungsi frasa dan kata majemuk itu sendiri. Fungsi di sini memiliki tujuan khusus dalam penggunaan bahasa (lihat Kridalaksana, 1982:48) sehingga apa yang diinginkan oleh Mohamad bisa tersampaikan. Hal ini bisa berfungsi puitis/estetis, yaitu penggunaan bahasa demi keindahan bahasa itu sendiri. Sementara itu, fungsi komunikatif adalah penggunaan bahasa untuk menyampaikan informasi antara pembicara (penulis) dan pendengar (pembaca).Fungsi referensial adalah penggunaan bahasa untuk menunjuk hal, benda, orang peristiwa, dan lainnya, yang ada di luar pembicara dan pendengar.

Lantas apakah hanya itu saja yang bisa didapatkan?. Satuan lingual (dalam hal ini frasa dan kata majemuk) memiliki fungsi dalam sebuah wacana. Misalnya,hal ini tidak bisa melepaskan makna yang ada di dalamnya. Melihat bahwa keduanya berada dalam sebuah wacana yang sarat estetika, jenis makna dalam frasa dan kata majemuk bisa terdiri atas beberapa macam (lihat Kridalaksana, 1982 dan Chaer, 2012), misalnya makna denotasi (makna kata atau kelompok kata yang didasarkan pada penunjukan yang lugas pada sesuatu di luar bahasa atau yan didasarkan atas konvensi tertentu), makna konotasi, makna gramatikal (hubungan antara unsur-unsur bahasa dalam satuan-satuan yang lebih besar misalnya hubungan antara kata dengan 
kata lain dalam frase atau klausa) dan makna kiasan (pemakaian kata dengan makna yang tidak sebenarnya) atau makna idiom (maknanya tidak dapat "diramalkan" baik secara leksikal maupun gramatikal).

Dengan demikian, frasa dan kata majemuk memiliki kompleksitas makna dan fungsi sehingga pada kenyataannya banyak kesulitan dalam memisahkan frasa dan kata majemuk. Meskipun ada yang mencoba memisahkan keduanya berdasarkan bentuk, tanpa makna itu sangat sulit sehingga dengan melihat bentuk dan makna, kiranya mereka dapat dipisahkan. Namun dalam hal wacana yang berbentuk puisi, segmentasi antara frasa dan kata majemuk haruslah jeli sebagai pijakan teori yang terkonsentrasi pada bentuk dan makna kiranya bisa membantu seseorang dalam pemisahan itu sendiri tanpa melupakan bagaimana fungsi keduanya dalam sebuah puisi.

Metode penelitian yang digunakan adalah metode kualitatif dengan teknik simak catat. Penelitian kualitatif baik data maupun hasil yang diperoleh dalam penelitian ini adalah data verbal yang berupa frasa dan kata majemuk yang ditemukan dalam kumpulan puisi Don Quixote. Oleh karena itu, teknik pengumpulan data yang digunakan penelitian ini adalah teknik pembacaan dan teknik pencatatan atau simak catat.

Objek penelitian ini adalah kumpulan puisi Don Quixote karya Goenawan Mohamad yang diterbitkan oleh Penerbit Tempo. Kumpulan puisi ini terdiri dari 19 puisi dan dua puisi yang menjadi sampel dan objek kajian dalam penelitian ini. Penelitian ini difokuskan pada frasa dan kata majemuk yang terdapat di dalam buku kumpulan puisi Don Quixote. Penelitian ini juga memfokuskan pada puisi yang memiliki jumlah frasa dan kata majemuk yang paling dominan agar membatasi ruang lingkup penelitian serta relasi antara fungsi dan makna diantara frasa dan kata majemuk. Teknik analisis data yang digunakan dalam penelitian ini adalah teknik deskriptif kualitatif. Teknik ini digunakan mengingat datadata dalam penelitian ini berupa data verbal yang memerlukan penjelasan secara deskriptif yang disajikan secara formal dan informal.

\section{HASIL DAN PEMBAHASAN}

Sesuai dengan rumusan masalah, penelitian ini mengkaji tentang jenis, fungsi, dan makna pada frasa dan kata majemuk dalam kumpulan puisi Don Quixote karya Goenawan Mohamad. Puisi yang berjumlah sembilan belas judul dan semuanya bercerita tentang Don Quixote. Puisi satu dan dua merupakan awal cerita dalam puisi yang memperkenalkan tokoh sentral. Penulis puisi ini menggunakan rangkaian kata-kata yang puitis dalam rangka menyampaikan sesuatu yang diinginkannya melalui kata-kata dan frasa yang teruntai secara sistematis.

Pemisahan atau klasifikasi frasa dan kata majemuk ditentukan berdasarkan teori-teori yang menjelaskan perbedaan di antara keduanya yakni Sportiche, Koopman, dan Stabler (2014), Chaer (2012) dan Kridalaksana (1982). Dalam hal ini, kesamaan persepsi di antara mereka adalah pada perbedaan bentuk atau struktur dan makna yang 
ditimbulkan dari satuan lingual itu sendiri. Hal ini bisa dilihat dari frasa dan kata majemuk yang membentuk rangkaian cerita ini beserta klasifikasi frasa dan kata majemuk dalam puisi di bawah ini.

Tabel 1

Klasifikasi Frasa dan Kata Majemuk Puisi 1 Don Quixote

\begin{tabular}{|c|c|c|}
\hline Puisi & Frasa & Kata Majemuk \\
\hline $\begin{array}{l}\text { Ia menangis } \\
\text { Untuk lelakidi atas kuda kurus } \\
\text { Yang akhirnya sampaipada teluk } \\
\text { Di mana fantasi adalah hijau hujan } \\
\text { Yang hilang ujung di laut asing }\end{array}$ & $\begin{array}{l}\text { Frasa preposisional: } \\
\text { Untuk lelaki, di atas kuda kurus, } \\
\text { pada teluk, } \\
\text { di laut asing } \\
\text { Frasa nominal: } \\
\text { Kuda kurus } \\
\text { Frasa verbal: } \\
\text { Yang akhirnya sampai } \\
\end{array}$ & $\begin{array}{l}\text { Hijau hujan } \\
\text { yang hilang ujung } \\
\text { laut asing }\end{array}$ \\
\hline $\begin{array}{l}\text { Ia menangis, dan lelaki itu } \\
\text { mendengarnya, "Aku Don Quixote } \\
\text { de La Mancha Majenun yang } \\
\text { mencarimu." }\end{array}$ & $\begin{array}{l}\text { Frasa determiner: } \\
\text { Lelaki itu }\end{array}$ & \\
\hline $\begin{array}{l}\text { Tubuhnya agak tinggi, tapi } \\
\text { rapuh dan tua sebenarnya. Ia } \\
\text { berdiri kaku. Cinta tampak telah } \\
\text { menyihirnya jadi ksatria dengan } \\
\text { luka di lambung. } \\
\text { Tapi ia menanti perempuan itu } \\
\text { melambai dalam interval gerimis } \\
\text { sebelum jalan ditutup dan mereka } \\
\text { mengirim polisi, } \\
\text { Tanda waktu, kematian. } \\
2007\end{array}$ & $\begin{array}{l}\text { Frasa determiner: } \\
\text { Tubuhnya } \\
\text { Frasa ajektiva: } \\
\text { Agak tinggi, rapuh dan tua, } \\
\text { rapuh dan tua sebenarnya } \\
\text { Frasa preposisional: } \\
\text { Dengan luka di lambung, dengan } \\
\text { luka, di lambung } \\
\text { Frasa verbal: } \\
\text { Berdiri kaku } \\
\text { Frasa nominal: } \\
\text { Tanda waktu, interval gerimis }\end{array}$ & \\
\hline
\end{tabular}

Kesamaan persepsi antara

Sportiche, Koopman, dan Stabler (2014), Chaer (2012) dan Kridalaksana (1982) mengenai perbedaan bentuk atau struktur dan makna yang ditimbulkan dari satuan lingual itu sendiri jugabisa dilihat pada frasa dan kata majemuk yang ada dalam sajak ke 2 puisi Don Quixote yang membentuk rangkaian cerita ini beserta klasifikasi frasa dan kata majemuk yang ada dalam puisi di bawah ini. 
Tabel 2

Klasifikasi Frasa dan Kata Majemuk Puisi 2 Don Quixote

\begin{tabular}{|c|c|c|}
\hline Puisi & Frasa & Kata Majemuk \\
\hline $\begin{array}{l}\text { Ke arah balkon } \\
\text { Ke arah balkon itu Don Quixote } \\
\text { de La Mancha bertanya, "Ke arah } \\
\text { manakah jalan ke kastil yang dulu } \\
\text { ada dan kini tidak?" }\end{array}$ & $\begin{array}{ll}\text { 1. Frasa preposisional: ke } \\
\text { arah balkon, ke arah balkon } \\
\text { itu, ke kastil } \\
\text { 2. Frasa nominal: arah balkon } \\
\text { 3. Frasa determiner: arah } \\
\text { balkon itu }\end{array}$ & \\
\hline $\begin{array}{l}\text { Seorang perempuan menengok ke } \\
\text { bawah sebentar. Rambutnyayang } \\
\text { lurus, hitam, membuat bayang } \\
\text { pada langsat pipinya. Matanya } \\
\text { kecil, mengingatkannya pada } \\
\text { punai yang terbidik. }\end{array}$ & 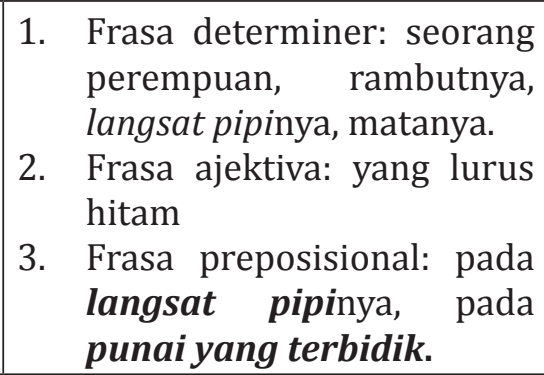 & $\begin{array}{l}\text { 1. langsat pipi } \\
\text { 2. punai yang } \\
\text { terbidik }\end{array}$ \\
\hline \multicolumn{3}{|l|}{ “Engkau ketakutan!” } \\
\hline $\begin{array}{l}\text { Dan laki-laki yang merasa dirinya } \\
\text { gagah itu pun turun dari kudanya. }\end{array}$ & $\begin{array}{l}\text { 1. Frasa verbal: yang merasa } \\
\text { 2. Frasa determiner: kudanya } \\
\text { 3. Frasa preposisional: dari } \\
\text { kudanya }\end{array}$ & \\
\hline $\begin{array}{l}\text { Ia berjalan mendekat. Ia melihat, } \\
\text { sekilas, tangan Peri Kesepian } \\
\text { mengangkat tubuh rapuh ituke } \\
\text { dalam sebuah gumpalan mega, } \\
\text { di mana setiap perempuanakan } \\
\text { ditinggalkan. }\end{array}$ & 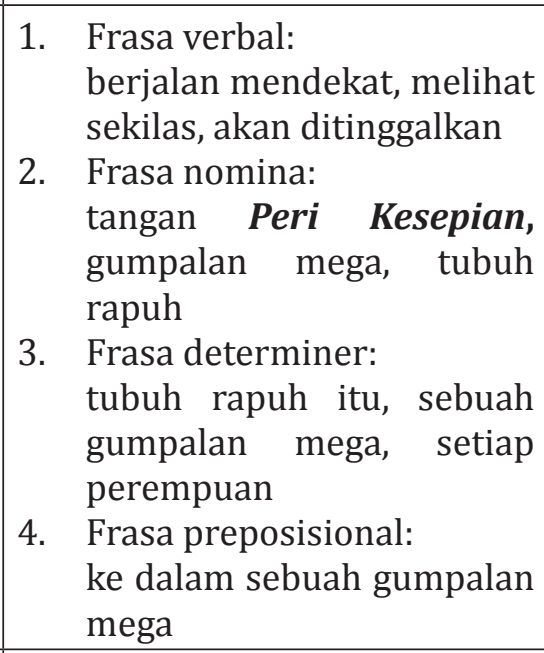 & 1. peri kesepian \\
\hline \multicolumn{3}{|l|}{ "Jangan!" } \\
\hline $\begin{array}{l}\text { Don Quixote menghunus } \\
\text { pedangnya yang retak. Tapi semua } \\
\text { bergerak pelan. } \\
2007\end{array}$ & \begin{tabular}{|ll} 
1. & Frasa determiner: \\
& pedangnya \\
2. & Frasa nomina: \\
& pedangnya yang retak \\
3. & Frasa verba: \\
& bergerak pelan \\
\end{tabular} & \\
\hline
\end{tabular}


Puisi-puisi tersebut, yakni pada sajak 1 dan 2, terlihat bahwa frasa-frasa yang ada berupa frasa determiner, frasa nominal, frasa ajektiva, frasa verbal, dan frasa preposisional, memiliki fungsifungsi yang dapat dilihat berdasarkan penggunaannya atau untaian di dalam puisi ini. Sebelum melihat fungsi, hal yang terlebih dahulu, makna merupakan hal yang sangat utama dalam menentukan klasifikasi sebuah satuan lingual. Berdasarkan asumsi itu, frasa pada puisi satu Don Quixote yang terdiri dari frasa determiner, frasa nominal, frasa ajektiva, frasa verbal dan frasa preposisional memiliki makna denotasi dan gramatikal. Sementara itu, kata majemuk didasarkan pada makna konotasi, kiasan, dan idiom.

Ada hal menarik yang bisa terlihat bahwa frasa determiner dan frasa preposisional bila mengalami eliminasi akan menyisakan frasa nominal sebagai hasil akhir yang jelas. Sebab, hal ini menunjukkan bahwa, dalam puisi ini, frasa nominal sebagai satuan lingual memiliki peranan besar dan dominan dalam fungsi referensial. Contoh berikut adalah konstruksi frasa dan kata majemuk yang menjadi dasar dalam melakukan klasifikasi.
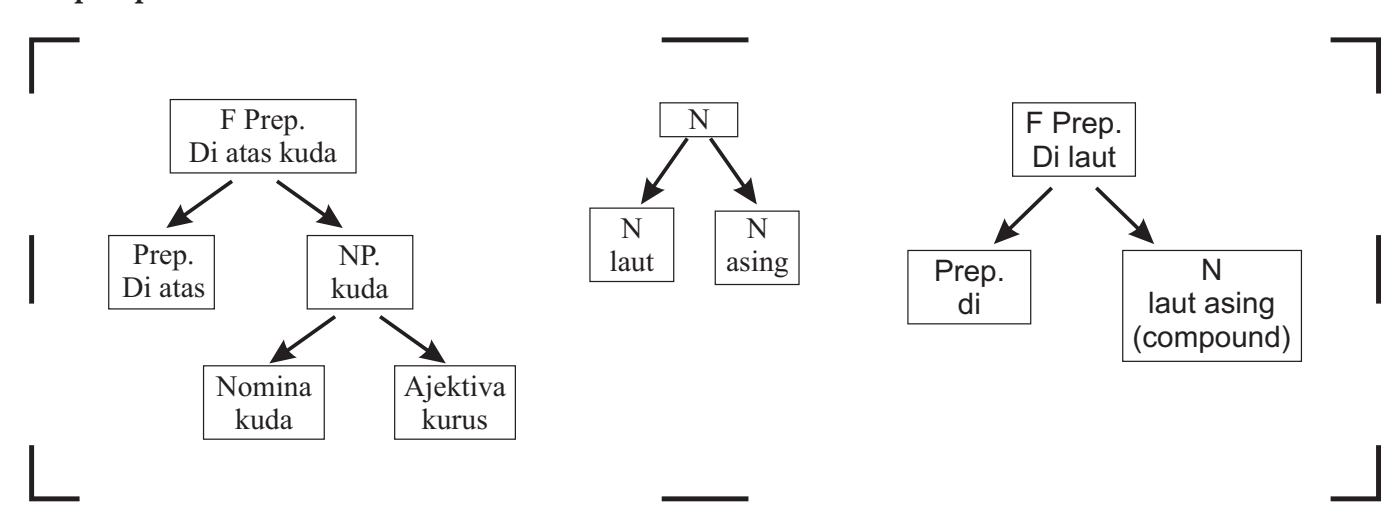

Gambar 1. Konstruksi frasa dan kata majemuk

Ada juga hal menarik lainnya bahwa sebuah frasa bisa terbentuk melalui kata dan kata majemuk yang ada pada frasa preposisional. Frase itu adalah di“laut asing”(sajak 1) dan"pada langsat pipinya, pada punai yang terbidik" (sajak 2); dan frasa nomina: "tanganPeri Kesepian".

Secara fungsi referensial, hal itumemperlihatkan bahwa frasa determiner dan frasa nominal menunjukkan partisipan dalam cerita yang disampaikan, baik partisipan kongkrit ataupun abstrak. Sebagai contoh adalah "kuda kurus", "interval gerimis", dan "tanda waktu". Senada dengan frasa determiner dan frasa nomina yang merujuk pada wujud nomina baik kongkrit ataupun abstrak, frasa preposisional juga menunjukkan kecenderungan pada partisipan dan lokasi atau keterangan tempat seperti "untuk lelaki", "di atas kuda kurus", "pada teluk", "di laut asing", "dengan luka di lambung", "dengan luka”, dan"di lambung".

Frasa nominal, frasa determiner, dan frasa preposisional memiliki fungsi referensial memiliki kecenderungan pada partisipan dan lokasi atau 
keterangan tempat. Selanjutnya, frasa verbal yang menunjukkan tindakan dan proses perbuatan dari partisipan yang terlihat pada "yang akhirnya sampai"dan "berdiri kaku". Frasa ajektiva menunjukkan keadaan partisipan secara fisik seperti "agak tinggi", "rapuh dan tua", "rapuh dan tua sebenarnya". Berdasarkan hal ini, hal itu terlihat bahwa frasa verbal dan memiliki fungsi referensial yang menunjukkan sesuatu yang dilakukan oleh partisipan dan keadaannya utamanya secara fisik dalam puisi satu dan dua.

Frasa-frasa dan kata majemuk juga memiliki fungsi yang perlu diperhatikan dalam puisi satu dan dua, Don Quixote, yang disebut dengan fungsi estetis yang memiliki efek puitis demi keindahan rangkaian kata dalam puisi yang memberikan pengaruh keindahan. Hal ini menunjukkan bahwa estetis yang selama ini cenderung diasumsikan dengan makna konotasi dan kiasan bisa dipertanyakan. Hal ini dibuktikan dengan eksistensi dari frasa-frasa yang ada pada tabel satu dan dua yang menunjukkan tentang keindahan yang terbentuk dari frasa yang memiliki makna denotasi dan gramatikal. Pada akhirnya, fungsi referensial dan estetis yang ada terakumulasi ke dalam fungsi komunikatif yang digunakan oleh penyair untuk menyampaikan apa yang ingin dia sampaikan.

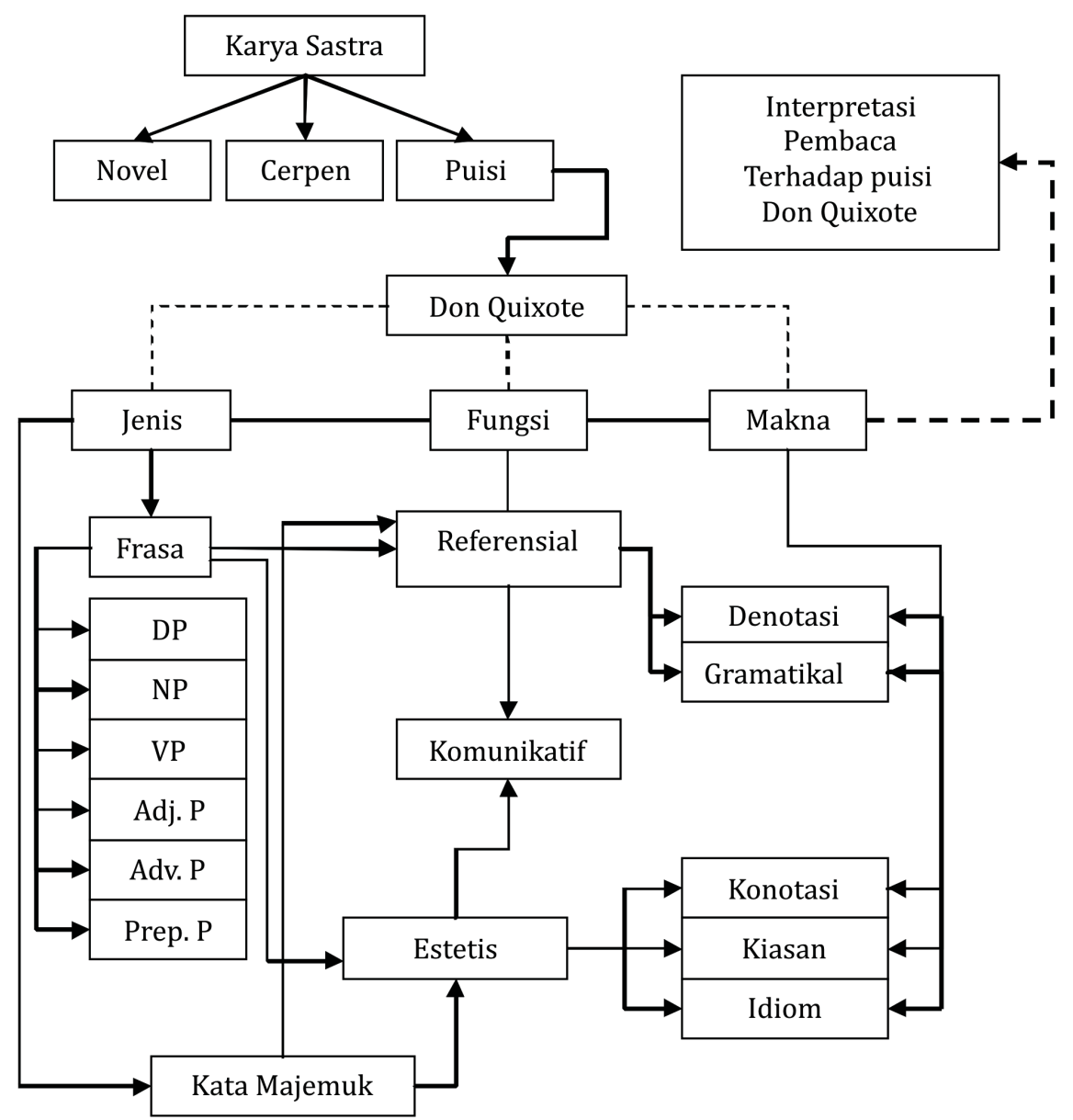

Gambar 2

Relasi antara Frasa \& Kata Majemuk pada Fungsi dan Makna 
Pada kata majemuk yang ada pada puisi satu dan dua, Don Quixote, adalah "hijau hujan", "yang hilang ujung", "laut asing dan langsat pipi", "punai yang terbidik", dan "Peri Kesepian". Hal ini terlihat jelas tentang kata ini secara bentuk hampir terlihat sebagai frasa. Namun, secara makna, hal itu tidak memenuhi yang disyaratkan sebagai frasa berdasarkan teori-teori yang ada pendahuluan utamanya makna gramatikal. Atau dengan kata lain, makna yang ada pada kata majemuk ini memiliki makna yang berbeda secara keseluruhan.

Ditinjau dari segi fungsi, kata majemuk dalam puisi satu dan dua, Don Quixote, telah jelas memiliki fungsi estetis yang memberikan efek keindahan. Makna secara kiasan dan konotasi memberikan pengaruh yang sangat besar. Akan tetapi, hal ini tidak memiliki fungsi seperti frasa yang memiliki fungsi referensial yang memberikan pengacuan, perbuatan, keadaan ataupun acuan lainnya secara denotasi dan gramatikal. Namun, efek puitis dari fungsi estetis atau puitis ini secara tidak langsung telah memberikan pengaruh besar pada fungsi komunikasi dalam puisi ini. Hal ini yang berarti bahwa, seperti yang telah disebutkan pada paragraf sebelumnya, efek puitis yang tercermin dari frasa dan kata majemuk telah memberi sesuatu yang besar kepada fungsi komunikatif yang ingin disampaikan oleh penyair. Pesan penyair telah tersampaikan baik tersirat dan tersurat melalui makna yang ditimbulkan dari frasa. Kata majemuk diinterpretasikan oleh pembaca berdasarkan interpretasi mereka sendiri.

Tabel 3

Rekapitulasi Frasa dan Kata Majemuk Puisi 1 dan 2 Don Quixote

\begin{tabular}{|c|c|c|c|c|c|c|c|c|}
\hline \multirow{2}{*}{ Puisi } & \multicolumn{7}{|c|}{ Frasa } & \multirow{2}{*}{$\begin{array}{c}\text { Kata } \\
\text { Majemuk }\end{array}$} \\
\hline & FD & FN & FV & F Adj. & F Adv. & F Prep. & $\sum$ & \\
\hline 1 & 2 & 3 & 2 & 3 & - & 7 & 17 & 3 \\
\hline 2 & 10 & 5 & 5 & 1 & - & 7 & 28 & 3 \\
\hline$\sum$ & 12 & 8 & 7 & 4 & - & 14 & 45 & 6 \\
\hline Ket. & \multicolumn{8}{|c|}{$\begin{array}{l}\text { FD = Frasa Determiner; FN = Frasa Nomina; FV = Frasa Verba, } \mathrm{F} \text { Adj. }= \\
\text { Frasa Ajektiva; F Adv. = Frasa Adverbia; F Prep. = Frasa Preposisional }\end{array}$} \\
\hline
\end{tabular}

Meskipun puisi Don Quixote adalah karya sastra yang sarat makna dan memiliki efek puitis yang besar seperti puisi pada umumnya dimana interpretasi pendengar dan pembaca juga menentukan apa yang disampaikan oleh penyair, efek puitis tidak dicerminkan dari kata majemuk yang sarat makna berbeda dari leksemleksem penyusunnya. Akan tetapi, efek puitis itu tersusun dari dominasi frasafrasa pada sajak satu dan dua yang tercermin secara langsung pada tabel 3.

Pada sajak satu, dari 17 frasa, ada terlihatfrasa preposisiyanglebih banyak daripada yang lain. Hal ini dikarenakan, pada sajak ini, penyair menggunakan 
frasa ini untuk menunjukkan partisipan, lokasi atau tempat (lihat pada tabel 1). Di sisi lain, ada keseimbangan antara frasa nomina yang digunakan penyair untuk menunjukkan partisipan ataupun referen yang bersifat abstrak dan frasa ajektiva untuk menunjukkan kondisi dari partisipan dalam sajak satu. Sementara itu, frasa verba yang merupakan rujukan mengenai proses ataupun tindakan dari partisipan seimbang dengan frasa determiner yang menunjukkan partisipan (serupa dengan frasa preposisi dan nomina). Sementara itu, kata majemuk yang berada di dalamnya hanya terdiri dari tiga kata saja. Dalam puisi ke dua, frasa determiner dan frasa preposisional yang menunjukkan partisipan lebih banyak digunakan dibandingkan frasa verba dan frasa ajektiva. Selain itu, kata majemuk juga sama dengan pada sajak pertama.

Berdasarkan tabel 3, hal itu menunjukkan bahwa penyair lebih cenderung banyak menggunakan fungsi referensial, terutama dalam menunjukkan partisipan, lokasi atau tempat dalam rangkaian cerita yangd ia sampaikan. Hal ini dikarenakan pada puisi Don Quixote dari puisi satu hingga 19 lebih banyak terfokus pada partisipan, lokasi atau tempat (lihat Mohamad, 2011:1-82). Kata majemuk digunakan dalam fungsi puitis walaupun hal itu tidak menutup kemungkinan juga merujuk pada referensial. Namun, fungsi referensial yang mendominasi inilah yang membantu penyair dalam menyampaikan sesuatu yang ingin disampaikan olehnya. Akibatnya, fungsi referensial ini juga memiliki fungsi puitis yang terakumulasi dalam fungsi komunikatif.

\section{SIMPULAN}

Penelitian ini sampai pada kesimpulan bahwa frasa dalam karya sastra meski memiliki makna gramatikal dan fungsi referensial ternyata juga berfungsi secara estetis dan komunikatif. Demikian pula kata majemuk yang secara makna telah jelas merepresentasikan fungsi estesis-nya dalam puisi Don Quixote. Namun, pada kenyataannya,dia juga bisa memiliki fungsi referensial yang semakin jelas bila kita melihat frasa itu sendiri. Hal ini bisa dilihat pada beberapa frasa yang terdiri dari kata majemuk. Makna kata majemuk itu sendiri juga mengacu pada sesuatu sehingga dapat dikatakan bahwa kata majemuk memiliki fungsi estetis, fungsi komunikatif, dan fungsi referensial. Meskipun hal itu tidak sedominan dari frasa-frasa yang ada dalam puisi. Pada akhirnya, frasa dan kata majemuk yang memiliki fungsi referensial dan estetis yang terakumulasi ke dalam fungsi komunikasi kemungkinan dapat mengakibatkan perbedaan interpretasi pembaca atau pendengar puisi Don Quixote, berdasarkan makna yang tertangkap dalam kognisi mereka. 
Ilfan A. P., Kun Andyan A., M. Eosyidi - Jenis, Fungsi, dan Makna pada Frase ...

\section{DAFTAR PUSTAKA}

Carnie, A. (2002). Syntax: A Generative introduction. Cornwall: T.J. International Ltd.

Chaer, A. (2012). Linguistik umum. Jakarta: PT Rineka Cipta.

Kridalaksana, H. (1982). Kamus linguistik. Jakarta: PT Gramedia.

Matthews, P. H. (1981). Syntax. Avon: The Bath Press.

Mohamad, G. (2011). Kumpulan sajak: don quixote. Tempo: Jakarta.

Nurgiyantoro, B. (2014). Stilistika. Yogyakarta: UGM Press.

Suminto, A.S. (2008). Berkenalan dengan puisi. Yogyakarta: Gama Media.

Sportiche et al. (2014). An Introduction to syntactic analysis and theory. West Sussex: Wiley Blackwell. 